\title{
Hydrogen Phosphate Selectively Induces MDA-MB- 231 Breast Cancer Cell Death in vitro
}

\author{
Aya Shanti \\ Khalifa University of Science and Technology \\ Kenana Al Adem \\ Khalifa University of Science and Technology \\ Cesare Stefanini \\ Khalifa University of Science and Technology \\ Sungmun Lee ( $\boldsymbol{\nabla}$ sung.lee@ku.ac.ae) \\ Khalifa University of Science and Technology
}

\section{Research Article}

Keywords: Breast Cancer, Phosphate, Hydrogen Phosphate, pH, and Toxicity

Posted Date: October 12th, 2021

DOl: https://doi.org/10.21203/rs.3.rs-956711/v1

License: (9) This work is licensed under a Creative Commons Attribution 4.0 International License. Read Full License 


\section{Abstract}

Phosphate ions are the most abundant anions inside the cells, and they are increasingly gaining attention as key modulators of cellular function and gene expression. However, little is known about the effect of inorganic phosphate ions on cancer cells, particularly breast cancer cells. Here, we investigated the toxicity of different phosphate compounds to triple-negative human breast cancer cells (MDA-MB-231) and compared it to that of human monocytes (THP-1). We found that, unlike dihydrogen phosphate $\left(\mathrm{H}_{2} \mathrm{PO}_{4}{ }^{-}\right)$, hydrogen phosphate $\left(\mathrm{HPO}_{4}{ }^{2-}\right)$ at $20 \mathrm{mM}$ or lower concentrations induced breast cancer (MDAMB-231) cell death more than immune (THP-1) cell death. We correlate this effect to the fact that phosphate in the form of $\mathrm{HPO}_{4}{ }^{2-}$ raises $\mathrm{pH}$ levels to alkaline levels which are not optimum for transport of phosphate into cancer cells. The results in this study highlight the importance of further exploring hydrogen phosphate $\left(\mathrm{HPO}_{4}{ }^{2-}\right)$ as a potential therapeutic for the treatment of breast cancer.

\section{Introduction}

Inorganic phosphate $\left(\mathrm{P}_{\mathrm{i}}\right)$ is a vital nutrient for all living things. It plays a crucial role in various physiological processes such as energy metabolism, lipid biosynthesis, nucleic acid biosynthesis, cellular differentiation, cellular repair and cellular signaling ${ }^{1,2}$. The main source of $P_{i}$ intake for humans is the diet, where $\mathrm{P}_{\mathrm{i}}$ exists in one of three anionic forms; $\mathrm{HPO}_{4}{ }^{2-}, \mathrm{H}_{2} \mathrm{PO}_{4}{ }^{-}$or $\mathrm{H}_{3} \mathrm{PO}_{4}{ }^{2}$. In the body, serum $\mathrm{P}_{\mathrm{i}}$ levels are precisely maintained within a specific range via the interplay between several organs including intestine, kidney, parathyroid gland and bones. Similarly, extracellular $\mathrm{P}_{\mathrm{i}}$ levels are maintained within a narrow range; between 0.7 and $1.55 \mathrm{mM}^{2-4}$.

Many studies have proposed the existence of a phosphate sensing mechanism in the body capable of detecting both serum and extracellular phosphate fluctuations and subsequently relaying this information to the cells, the local environment and/or the whole body ${ }^{5-7}$. Interestingly, several findings have revealed that extracellular phosphate in itself carries out this function by acting as a signaling molecule ${ }^{6,8-12}$. The interior environment of the cell is electronegative compared to the exterior one, thus, the transport of $\mathrm{P}_{\mathrm{i}}$ into the cell does not happen by simple diffusion, but instead is mediated by $\mathrm{Na}^{+}-$ coupled $\mathrm{P}_{\mathrm{i}}$ cotransporters, which are highly regulated proteins ${ }^{4,5,13}$. Furthermore, $\mathrm{P}_{\mathrm{i}}$ can initiate signal transduction pathways, alter gene expression and regulate diverse cellular functions ${ }^{7,9,14,15}$. All these evidence serve to pinpoint the importance of $\mathrm{P}_{\mathrm{i}}$ in the body and to highlight the significance of regulating $P_{\mathrm{i}}$ levels.

Recently, high $\mathrm{P}_{\mathrm{i}}$ intake and high $\mathrm{P}_{\mathrm{i}}$ serum levels were associated with higher morbidity and mortality rates ${ }^{16,17}$. In fact, high serum concentrations are associated with kidney disease, perturbed brain growth, vascular calcification and cardiovascular events ${ }^{16-19}$. However, the mechanisms by which high $P_{i}$ concentrations are linked to tissue damage are not completely understood. Shuto et.al showed that $P_{i}$ acutely impairs endothelial function by increasing production of reactive oxygen species and decreasing 
production of nitric oxide ${ }^{20}$. On the other hand, how phosphate affects diseased cells, particularly cancer cells, is only minimally explored ${ }^{21,22}$. For instance, Spina et.al demonstrated that $\mathrm{P}_{\mathrm{i}}$ inhibits proliferation of human osteosarcoma U20S cells as well as MDA-MB-231 cells but did not explore its effect on normal, healthy cells $14,23,24$.

In this study, we investigated the toxicity of different phosphate compounds to triple-negative human breast cancer cells (MDA-MB-231) and to human monocytes (THP-1). We demonstrated that, unlike phosphate in the form of dihydrogen phosphate $\left(\mathrm{H}_{2} \mathrm{PO}_{4}{ }^{-}\right)$, hydrogen phosphate $\left(\mathrm{HPO}_{4}{ }^{2-}\right)$ induces breast cancer cell death but not immune cell death. We attribute this effect to the fact that phosphate in the form of $\mathrm{HPO}_{4}{ }^{2-}$ raises $\mathrm{pH}$ levels to alkaline levels which are not optimum for phosphate transport into cancer cells. Taken together, these results indicate the significance of further exploring $\mathrm{HPO}_{4}{ }^{2-}$ as potential therapeutic for the treatment of breast cancer.

\section{Results}

\section{Cytotoxicity of Different Phosphate Compounds}

In order to assess the effect of different phosphate compounds on the cell viability of MDA-MB-231 and THP-1 cells, three inorganic phosphates $\left(\mathrm{NaH}_{2} \mathrm{PO}_{4}, \mathrm{Na}_{2} \mathrm{HPO}_{4}\right.$, and $\left.\mathrm{KH}_{2} \mathrm{PO}_{4}\right)$ and three organic phosphates (adenosine triphosphate (ATP), adenosine diphosphate (ADP) and adenosine monophosphate (AMP)) were tested. Both MDA-MB-231 and THP-1 cells were incubated with $20 \mathrm{mM}$ of $\mathrm{NaH}_{2} \mathrm{PO}_{4}, \mathrm{Na}_{2} \mathrm{HPO}_{4}$, $\mathrm{KH}_{2} \mathrm{PO}_{4}, \mathrm{ATP}, \mathrm{ADP}$ and AMP for $48 \mathrm{~h}$, then assessed for their viability via MTT assay. As shown in Figure 1 , almost all phosphate-containing compounds were toxic (viability $<80 \%$ ) to both cell types and their toxicity was more pronounced on THP-1 cells than it was on MDA-MB-231 cells. Interestingly, only $\mathrm{Na}_{2} \mathrm{HPO}_{4}$ was more toxic to MDA-MB-231 cells than it was to THP-1 cells. In particular, the viability of MDA-MB-231 cells incubated with $20 \mathrm{mM} \mathrm{Na}_{2} \mathrm{HPO}_{4}$ was $37.5 \%$ lower than that of THP-1 (Relative viability of MDA-MB-231 was $54.1 \%$ while that of THP-1 was $86.6 \%$ ). This indicates that the toxicity of $\mathrm{Na}_{2} \mathrm{HPO}_{4}$ is selective to the cell type.

In order to understand the difference in the effect of the various phosphate compounds on the two cell types, the $\mathrm{pH}$ of the different phosphate solutions was measured. In Figure 2, all phosphate compounds produced acidic solutions except $\mathrm{Na}_{2} \mathrm{HPO}_{4}$ which produced a basic one.

This, as well as the fact that $\mathrm{Na}_{2} \mathrm{HPO}_{4}$ is the only compound containing phosphate in the form of $\mathrm{HPO}_{4}{ }^{2-}$, were a drive to further explore $\mathrm{Na}_{2} \mathrm{HPO}_{4}$ compound.

In the medium, inorganic phosphate compounds are dissociated into ions.

$\mathrm{NaH}_{2} \mathrm{PO}_{4} \leftrightarrow \mathrm{Na}^{+}+\mathrm{H}_{2} \mathrm{PO}_{4}^{-}$ 
$\mathrm{Na}_{2} \mathrm{HPO}_{4} \leftrightarrow 2 \mathrm{Na}^{+}+\mathrm{HPO}_{4}{ }^{2-}$

\section{$\mathrm{KH}_{2} \mathrm{PO}_{4} \leftrightarrow \mathrm{K}^{+}+\mathrm{H}_{2} \mathrm{PO}_{4}^{-}$}

$\mathrm{Na}_{2} \mathrm{HPO}_{4}$ produces phosphate ion in the form of $\mathrm{HPO}_{4}{ }^{2-}$, i.e. hydrogen phosphate.

\section{Effect of hydrogen phosphate $\left(\mathrm{HPO}_{4}{ }^{2-}\right)$ on MDA-MB-231 and THP-1 cell viability}

In order to further examine the effect of hydrogen phosphate $\left(\mathrm{HPO}_{4}{ }^{2-}\right)$ on viability of MDA-MB-231 and THP-1 cells, cells were incubated with different amounts of $\mathrm{NaHPO}_{4}$ for $48 \mathrm{~h}$ then assessed for their viability via MTT assay. Figure 3 demonstrated that, at low concentrations, $\mathrm{HPO}_{4}{ }^{2-}$ was more toxic to MDA-MB-231 cells than it was to THP-1 cells. Interestingly, for MDA-MB-231, even low concentrations (< $20 \mathrm{mM}$ ) caused a significant decrease in cell viability. For example, $5 \mathrm{mM} \mathrm{Na}_{2} \mathrm{HPO}_{4}$ reduced the viability of MDA-MB-231 by almost $20 \%$. However, for THP-1 cells, there was no significant decrease in the viability of cells incubated with 5,10 and $20 \mathrm{mM} \mathrm{NaHPO}_{4}$ compared to control cells. Only concentrations above $20 \mathrm{mM}$ produced a significant decrease in viability.

In order to confirm that the observed toxicity of $\mathrm{Na}_{2} \mathrm{HPO}_{4}$ on MDA-MB-231 was induced by phosphate and not by sodium in $\mathrm{NaHPO}_{4}$ or by simple osmotic pressure, the toxicity of $\mathrm{NaCl}$, sucrose and sodium bicarbonate on MDA-MB-231 was assessed. In Figure 4, none of the compounds caused a significant decrease in the viability of cells which indicates that the phosphate is the probable cause for the induced toxicity observed.

In order to explore the possible mechanisms of action in which $\mathrm{HPO}_{4}{ }^{2-}$ induces its toxicity, the effect of $\mathrm{HPO}_{4}{ }^{2-}$ on $\mathrm{pH}$ of the media was assessed. For that, phosphate solutions at different concentrations (5, $10,20,40,80,100$ and $120 \mathrm{mM}$ ) were prepared in media then their $\mathrm{pH}$ measured. As seen in Figure 5, results indicate that as the concentration of $\mathrm{HPO}_{4}{ }^{2-}$ increases, the $\mathrm{pH}$ of the solutions increases.

\section{Tolerance of MDA-MB-231 and THP-1 cells to different pH levels}

As $\mathrm{HPO}_{4}{ }^{2-}$ was found to alter the $\mathrm{pH}$ of the media, the difference in the tolerance of MDA-MB-231 and THP-1 cells to different $\mathrm{pH}$ levels was examined. For this, cells were incubated in media solutions at $\mathrm{pH}$ values equal to 5, 6, 7, 8 and 9 for $48 \mathrm{~h}$ then their viability determined using MTT assay. As seen in Figure 6 , results demonstrated that both cell types were more tolerant to basic conditions than they were to acidic conditions, and that MDA-MB-231 cells were slightly more tolerant to $\mathrm{pH}$ fluctuations than THP-1 cells were.

\section{Effect of Sodium Phosphate Dibasic at Physiological pH}


If MDA-MB-231 cells are more tolerant to $\mathrm{pH}$ fluctuations than THP-1 cells are, there should be another reason why $\mathrm{Na}_{2} \mathrm{HPO}_{4}$ is more toxic to MDA-MB-231 than it is to THP-1 cells. Our hypothesis is that this toxicity is related to the way phosphate is transported into cancer cells, particularly breast cancer cells. Several studies showed that breast cancer cells have high levels of Pi transporters compared to normal tissue ${ }^{25-27}$. These transporters, according to Forster et al., Russo-Abrahão et.al and Takeda, are sodium dependent and bind with high affinity to inorganic phosphate ${ }^{1,28,29}$. Interestingly, they have high affinity for $\mathrm{P}_{\mathrm{i}}$ in its diprotic form $\left(\mathrm{H}_{2} \mathrm{PO}_{4}\right)$, which exists at physiological $\mathrm{pH}$, and low affinity for $\mathrm{P}_{\mathrm{i}}$ in its monoprotic form $\left(\mathrm{HPO}_{4}{ }^{2-}\right)$, which exists at alkaline $\mathrm{pH}^{1}$. Since triple negative breast cancer cells are known to require elevated amounts of phosphate to meet their metabolic demands, failure to efficiently transport phosphate into cancer cells alters their functioning and probably leads to cellular death ${ }^{30,31}$. This study demonstrates that phosphate in its monoprotic form $\left(\mathrm{HPO}_{4}{ }^{2-}\right)$ causes significant death in MDA-MB-231 cells but not in THP-1 cells, unlike phosphate in its diprotic form.

Since phosphate in general is a tryptotic acid and, thus, has different physiological forms according to the $\mathrm{pH}$ range in which it is found, the effect of adding $\mathrm{Na}_{2} \mathrm{HPO}_{4}$ to MDA-MB-231 and THP-1 cells and then adjusting the $\mathrm{pH}$ to a physiological one $(\mathrm{pH}=7.4)$ was also explored ${ }^{32}$. As seen in Figure 7 , results demonstrated that adjusting the $\mathrm{pH}$ to physiological range after adding $\mathrm{HPO}_{4}{ }^{2-}$ slightly enhanced viability of MDA-MB-231 cells but had no effect on viability of THP-1 cells. The level of enhancement in viability was also $\mathrm{pH}$ dependent. These results support the hypothesis that cancer cells seem to favor diprotic form of phosphate than monoprotic one.

\section{Discussion}

In this study, we demonstrated the potential of $\mathrm{HPO}_{4}{ }^{2-}$ to contribute to the treatment of breast cancer cells. This is quite significant as there is no effective therapy for triple-negative breast cancer to date and it continues to acclaim the lives of its patients ${ }^{33,34} . P_{\mathrm{i}}$ is emerging as a crucial signaling molecule capable of altering signal transduction pathways, gene expression, and protein abundance in many cell types ${ }^{9,35-37}$. Interestingly, its effect on cells is not universal but varies according to the cellular type and cellular background. For instance, $\mathrm{P}_{\mathrm{i}}$ was shown to increase cell proliferation in some cell types, such as preosteoblastic cells, lung cells, and epidermal JB6 cells while decreasing proliferation in other cell types such as human osteosarcoma U2OS cells and MDA-MB-231 cells $3,19,23,23,35,38-41$. In addition, $P_{i}$ was shown to induce apoptosis in MO6-G3 odontoblast-like cells ${ }^{42}$. Interestingly, Spina et.al showed that Pi inhibits proliferation in MDA-MB-231 cells but not in MCF-7 breast cancer cells, which are not "triple negative" and express estrogen and progesterone receptors ${ }^{14}$. These results strongly suggest that $\mathrm{Pi}$ has discrete effects on cells depending on their type and background. Here, we also show that the specific type of phosphate available to the cells has a great influence on its response to it. In particular, hydrogen phosphate causes significant death in MDA-MB-231 cells but not in THP-1 cells, unlike dihydrogen phosphate. Schematic diagram of Figure 8 showed the effect of hydrogen phosphate on the cell viability of MDA-MB-231 and THP-1 cells. We correlate this effect to the fact that MDA-MB-231 cells require high 
amounts of phosphate to meet their metabolic needs but are unable to attain it due to the inability of phosphate transporters to carry phosphate into the cells when it is in the form of $\mathrm{HPO}_{4}{ }^{2-43}$. Studies show that cancer cells depend on several transporters to transport phosphate into the cells, but the key ones are sodium dependent transporters and hydrogen dependent transporters, both of which are highly

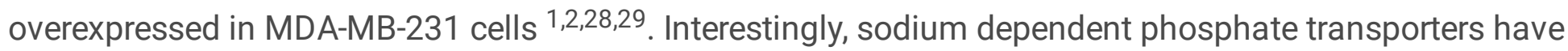
higher affinity for dihydrogen phosphate $\left(\mathrm{H}_{2} \mathrm{PO}_{4}\right)$ than they do to hydrogen phosphate $\left(\mathrm{HPO}_{4}{ }^{2-}\right)^{1}$. In addition, hydrogen dependent transporters tend to transport phosphate more efficiently in acidic conditions than they do in basic conditions due to the greater availability of protons $(\mathrm{H}+)$ in acidic environments compared to basic environments ${ }^{2}$. These findings are, in fact, in consistence with the results obtained from this study.

Finally, we suggest that hydrogen phosphate is a suitable candidate for further investigation as a therapeutic for the treatment of breast cancer, due to its selective ability to induce cell death in cancer cells but not in immune cells. This is quite crucial as effective cancer therapeutics require high antitumor activity and minimal toxicity to normal tissues.

\section{Materials And Methods}

\section{Cell culture}

MDA-MB-231 (ATCC, Manassas, VA, USA) cells were cultured in Dulbecco's Modified Eagle Medium (DMEM) containing $4.5 \mathrm{~g} / \mathrm{L}$ D-glucose, $0.584 \mathrm{~g} / \mathrm{L}$ L-Glutamine and $0.11 \mathrm{~g} / \mathrm{L}$ Sodium Pyruvate (Gibco, Fisher Scientific, Waltham, MA, USA). The media was supplemented with $10 \%$ Fetal Bovine Serum (FBS) (Gibco) and $1 \%$ penicillin-streptomycin (Gibco). The cells were incubated at $37^{\circ} \mathrm{C}$ and $5 \% \mathrm{CO}_{2}$.

THP-1 (ATCC) cells were cultured in Roswell Park Memorial Institute (RPMI) 1640 medium containing 4.5 $\mathrm{g} / \mathrm{L}$ D-glucose, $0.3 \mathrm{~g} / \mathrm{L}$ L-glutamine, and $0.11 \mathrm{~g} / \mathrm{L}$ sodium pyruvate (Gibco). The media was supplemented with $10 \%$ heat inactivated fetal bovine serum (FBS) and $1 \%$ penicillin-streptomycin (Gibco).

All cells were incubated at $37^{\circ} \mathrm{C}$ and $5 \% \mathrm{CO}_{2}$.

\section{Cytotoxicity of Different Phosphate Compounds}

To assess the toxicity of different phosphate compounds on MDA-MB-231 cells and on THP-1 cells, an MTT (3-(4,5-dimethylthiazol-2-yl)-2,5-diphenyltetrazolium bromide) (Sigma-Aldrich, St. Louis, MO, USA) reduction assay was performed. In brief, cells were seeded in 96 well plates at a concentration of $6 \times 10^{5}$ cells $/ \mathrm{mL}$ and incubated for $24 \mathrm{~h}$ at $37^{\circ} \mathrm{C}$ and $5 \% \mathrm{CO}_{2}$. After $24 \mathrm{~h}$ of incubation, $20 \mathrm{mM}$ of $\mathrm{NaH}_{2} \mathrm{PO}_{4}$, $\mathrm{KH}_{2} \mathrm{PO}_{4}, \mathrm{Na}_{2} \mathrm{HPO}_{4}, \mathrm{ATP}, \mathrm{ADP}$ and AMP were added to cells. Cells with media only and no phosphate were kept as a control. Cells were then incubated for an additional $48 \mathrm{~h}$. After $48 \mathrm{~h}$, MTT was added to the cells and the cells were subsequently incubated for extra $4 \mathrm{~h}$. During this incubation time, yellow MTT solution was reduced to purple formazan in living cells. After $4 \mathrm{~h}$, media containing MTT was removed from all 
wells and replaced by DMSO. The absorbance of each sample was then measured at $570 \mathrm{~nm}$ using the microplate reader (Tecan Trading AG, Zurich, Switzerland). Percentage of viable cells was calculated by comparing the absorbance of the control cells (cells with medium only and no phosphate) to that of cells with the phosphate. Percentage cell viability was calculated as: Percentage cell viability $=$ (cells with phosphate and MTT) / (control cells with MTT but no phosphate) $\times 100$.

\section{Cytotoxicity of Sodium Phosphate Dibasic}

To further examine the effect of phosphate in the form of $\mathrm{HPO}_{4}{ }^{2-}$ on MDA-MB-231 cells and on THP-1 cells, cells were incubated with different concentrations of $\mathrm{Na}_{2} \mathrm{HPO}_{4}$ for $48 \mathrm{~h}$ then their viability assessed. In brief, cells were seeded in 96 well plates at a concentration of $6 \times 10^{5}$ cells $/ \mathrm{mL}$ and incubated for $24 \mathrm{~h}$ at $37^{\circ} \mathrm{C}$ and $5 \% \mathrm{CO}_{2}$. After $24 \mathrm{~h}$ of incubation, $\mathrm{Na}_{2} \mathrm{HPO}_{4}$ was added to cells at variable concentrations ( 5 , $10,20,40,80,100$ and $120 \mathrm{mM}$ ). Cells with media only without $\mathrm{Na}_{2} \mathrm{HPO}_{4}$ were kept as a control. Cells were then incubated for an additional $48 \mathrm{~h}$. After $48 \mathrm{~h}$, MTT was added to cells and cells were subsequently incubated for extra $4 \mathrm{~h}$. After $4 \mathrm{~h}$, the absorbance of each sample was measured and subsequent cellular viability determined.

To confirm that any observed effects are due to phosphate and not to osmotic pressure or to sodium in $\mathrm{Na}_{2} \mathrm{HPO}_{4}, \mathrm{MTT}$ assay was performed to quantify the toxicity of sodium and the effect of osmotic pressure. In particular, cells were incubated with $20 \mathrm{mM}, 40 \mathrm{mM}, 60 \mathrm{mM}$ sucrose to examine the effect of osmotic pressure and with $20 \mathrm{mM}, 40 \mathrm{mM} \mathrm{NaCl}$ and $20 \mathrm{mM}$ sodium bicarbonate to examine effect of sodium.

\section{Measurement of $\mathrm{pH}$}

In order to investigate the possible ways in which phosphate influences MDA-MB-231 and THP-1 cell survival, the $\mathrm{pH}$ of the resultant solutions (after adding different phosphate compounds and after adding different concentrations of $\mathrm{Na}_{2} \mathrm{HPO}_{4}$ ) were measured using a pH meter (ORION STAR A211, Thermo Scientific, Waltham, MA, USA).

\section{Tolerance of MDA-MB-231 and THP-1 cells to different $\mathrm{pH}$ levels}

To study the tolerance of MDA-MB-231 and THP- 1 cells to different $\mathrm{pH}$ levels, cells were incubated for 48 $\mathrm{h}$ in media having $\mathrm{pH}$ levels ranging from 5-9 then their viability was assessed using MTT assay. In brief, MDA-MB-231 and THP-1 cells were seeded in 96 well plates at a concentration of $6 \times 10^{5}$ cells $/ \mathrm{mL}$ and incubated for $24 \mathrm{~h}$ at $37^{\circ} \mathrm{C}$ and $5 \% \mathrm{CO}_{2}$. After $24 \mathrm{~h}$ of incubation, the old media was replaced by new media having its $\mathrm{pH}$ adjusted by $\mathrm{HCl}$ (Sigma-Aldrich) or $\mathrm{NaOH}$ (Sigma-Aldrich) to obtain a specific $\mathrm{pH}$; either $5,6,8$ or 9 . Media without any addition of acid or base was kept as a control (pH 7.2). The cells were incubated for 48 hours. After 48 hours, MTT was added to cells and their viability was quantified.

\section{Toxicity of Sodium Phosphate Dibasic at Physiological pH}


To study the toxicity of $\mathrm{Na}_{2} \mathrm{HPO}_{4}$ on MDA-MB-231 and THP-1 cells at physiological $\mathrm{pH}$, cells were incubated for $48 \mathrm{~h}$ with $20 \mathrm{mM}$ sodium phosphate dibasic $\left(\mathrm{Na}_{2} \mathrm{HPO}_{4}\right)$ solutions having their $\mathrm{pH}$ adjusted to 7.4 then their viability was assessed via MTT assay. In brief, cells were seeded in 96 well plates at a concentration of $6 \times 10^{5} \mathrm{cells} / \mathrm{mL}$ and incubated for $24 \mathrm{~h}$ at $37^{\circ} \mathrm{C}$ and $5 \% \mathrm{CO}_{2}$. After $24 \mathrm{~h}$ of incubation, $20 \mathrm{mM} \mathrm{Na}_{2} \mathrm{HPO}_{4}$ at pH 8.1 and at pH 7.4 were added to the cells. Two controls were maintained for this experiment: cells kept in media only (negative control) and cells kept in media having its $\mathrm{pH}$ adjusted to 8 or 8.5 by $\mathrm{NaOH}$ (Sigma-Aldrich) (positive control). The cells were incubated for 48 hours. After $48 \mathrm{~h}$, MTT was added to cells and their viability was quantified.

\section{Data Analysis}

All experiments were done at least in triplicates. The data is presented as mean \pm standard error. Student t-test was performed to determine significance. $P<0.05$ was regarded as significant.

\section{Declarations}

\section{Author Contributions}

Conceptualization, A.S. and S.L.; methodology, A.S. and S.L.; validation, A.S., K.A. and S.L.; investigation, A.S., K.A., S.L.; resources, S.L.; data curation, S.L.; writing-original draft preparation, A.S.; writing-review and editing, K.A. and S.L.; visualization, A.S. and S.L.; supervision, S.L., C.S.; project administration, S.L. and C.S.; funding acquisition, S.L. and C.S. All authors have read and agreed to the published version of the manuscript.

\section{Acknowledgment}

This publication is based upon work supported by the Khalifa University of Science and Technology under Award No. RC2-2018-022 (Healthcare Engineering Innovation Centre).

\section{References}

1. Russo-Abrahão, T. et al. Characterization of inorganic phosphate transport in the triple-negative breast cancer cell line, MDA-MB-231.PLOS ONE13,e0191270(2018).

2. Lacerda-Abreu, M. A. et al. H+-dependent inorganic phosphate transporter in breast cancer cells: Possible functions in the tumor microenvironment.Biochim. Biophys. Acta BBA-Mol. Basis Dis.1865,2180-2188(2019).

3. Camalier, C. E. et al. Elevated Phosphate Activates N-ras and Promotes Cell Transformation and Skin Tumorigenesis. Cancer Prev. Res. (Phila. Pa.)3,359-370(2010).

4. Bhutia, Y. D. et al. SLC transporters as a novel class of tumour suppressors: identity, function and molecular mechanisms. Biochem. J.473,1113-1124(2016). 
5. Sapio, L. \& Naviglio, S. Inorganic phosphate in the development and treatment of cancer: A Janus Bifrons? World J. Clin. Oncol.6,198-201(2015).

6. Bergwitz, C. \& Jüppner, H. Phosphate sensing.Adv. Chronic Kidney Dis.18,132-144(2011).

7. Sabbagh, Y. Phosphate as a sensor and signaling molecule. Clin. Nephrol.79,57-65(2013).

8. Michigami, T., Kawai, M., Yamazaki, M. \& Ozono, K. Phosphate as a Signaling Molecule and Its Sensing Mechanism. Physiol. Rev.98,2317-2348(2018).

9. Khoshniat, S. et al. The emergence of phosphate as a specific signaling molecule in bone and other cell types in mammals. Cell. Mol. Life Sci.68,205-218(2011).

10. Michigami, T. Extracellular phosphate as a signaling molecule.Contrib. Nephrol.180,14-24(2013).

11. Miyamoto, K., Ito, M., Segawa, H. \& Kuwahata, M. Secondary hyperparathyroidism and phosphate sensing in parathyroid glands.J. Med. Investig. JMI47,118-122(2000).

12. Silver, J. \& Dranitzki-Elhalel, M. Sensing phosphate across the kingdoms:Curr. Opin. Nephrol. Hypertens.12,357-361(2003).

13. Tenenhouse, H. S. Phosphate transport: Molecular basis, regulation and pathophysiology.J. Steroid Biochem. Mol. Biol.103,572-577(2007).

14. Spina, A. et al. Inorganic Phosphate as a Novel Signaling Molecule with Antiproliferative Action in MDA-MB-231 Breast Cancer Cells.BioResearch Open Access2,47-54(2013).

15. Rendenbach, C. et al. Effects of extracellular phosphate on gene expression in murine osteoblasts. Calcif. Tissue Int.94,474-483(2014).

16. Anderson, J. J. B. Potential health concerns of dietary phosphorus: cancer, obesity, and hypertension.Ann. N. Y. Acad. Sci.1301,1-8(2013).

17. Calvo, M. S. \& Uribarri, J. Public health impact of dietary phosphorus excess on bone and cardiovascular health in the general population.Am. J. Clin. Nutr.98,6-15(2013).

18. Ellam, T. J. \& Chico, T. J. A. Phosphate: the new cholesterol? The role of the phosphate axis in nonuremic vascular disease. Atherosclerosis220,310-318(2012).

19. Jin, H. et al. A high inorganic phosphate diet perturbs brain growth, alters Akt-ERK signaling, and results in changes in cap-dependent translation. Toxicol. Sci. Off. J. Soc. Toxicol.90,221-229(2006).

20. Shuto, E. et al. Dietary Phosphorus Acutely Impairs Endothelial Function.J. Am. Soc. Nephrol.20,1504-1512(2009).

21. Cox, R. F., Jenkinson, A., Pohl, K., O’Brien, F. J. \& Morgan, M. P. Osteomimicry of Mammary Adenocarcinoma Cells In Vitro; Increased Expression of Bone Matrix Proteins and Proliferation within a 3D Collagen Environment.PLoS ONE7,e41679(2012).

22. Cox, R. F. et al. Microcalcifications in breast cancer: novel insights into the molecular mechanism and functional consequence of mammary mineralisation.Br. J. Cancer106,525-537(2012).

23. Naviglio, S. et al. Inorganic phosphate inhibits growth of human osteosarcoma U2OS cells via adenylate cyclase/cAMP pathway.J. Cell. Biochem.98,1584-1596(2006). 
24. Spina, A. et al. Inorganic phosphate enhances sensitivity of human osteosarcoma U2OS cells to doxorubicin via a p53-dependent pathway.J. Cell. Physiol.228,198-206(2013).

25. Chen, D. R. et al. SLC34A2 as a novel marker for diagnosis and targeted therapy of breast cancer.Anticancer Res.30,4135-4140(2010).

26. Ge, G. et al. Enhanced SLC34A2 in breast cancer stem cell-like cells induces chemotherapeutic resistance to doxorubicin via SLC34A2-Bmi1-ABCC5 signaling. Tumor Biol.37,5049-5062(2016).

27. Lv, Y. et al. The effects and mechanisms of SLC34A2 on maintaining stem cell-like phenotypes in CD147 ${ }^{+}$breast cancer stem cells. Tumor Biol.39,101042831769592(2017).

28. Forster, I. C., Hernando, N., Biber, J. \& Murer, H. Phosphate transporters of the SLC20 and SLC34 families.Mol. Aspects Med.34,386-395(2013).

29. Takeda, E. et al. Inorganic phosphate homeostasis and the role of dietary phosphorus.J. Cell. Mol. Med.8,191-200(2004).

30. Moreno-Sánchez, R., Rodríguez-Enríquez, S., Marín-Hernández, A. \& Saavedra, E. Energy metabolism in tumor cells. FEBS J.274,1393-1418(2007).

31. Lacerda-Abreu, M. A. et al. Ectophosphatase activity in the triple-negative breast cancer cell line MDA-MB-231. Cell Biol. Int.45,411-421(2021).

32. Biber, J., Hernando, N. \& Forster, I. Phosphate Transporters and Their Function.Annu. Rev. Physiol.75,535-550(2013).

33. Rakha, E. A. \& Chan, S. Metastatic Triple-negative Breast Cancer.Clin. Oncol.23,587-600(2011).

34. Pal, S. K., Childs, B. H. \& Pegram, M. Triple negative breast cancer: unmet medical needs.Breast Cancer Res. Treat.125,627-636(2011).

35. Jin, H. et al. High dietary inorganic phosphate increases lung tumorigenesis and alters Akt signaling.Am. J. Respir. Crit. Care Med.179,59-68(2009).

36. Takeda, E., Taketani, Y., Sawada, N., Sato, T. \& Yamamoto, H. The regulation and function of phosphate in the human body.BioFactors Oxf. Engl.21,345-355(2004).

37. Spina, A. et al. Inorganic phosphate as a signaling molecule: a potential strategy in osteosarcoma treatment.Curr. Pharm. Des.19,5394-5403(2013).

38. Beck, G. R. Inorganic phosphate as a signaling molecule in osteoblast differentiation.J. Cell. Biochem.90,234-243(2003).

39. Kemi, V. E., Kärkkäinen, M. U. M. \& Lamberg-Allardt, C. J. E. High phosphorus intakes acutely and negatively affect $\mathrm{Ca}$ and bone metabolism in a dose-dependent manner in healthy young females. $\mathrm{Br}$. J. Nutr.96,545-552(2006).

40. Jin, H. et al. High dietary inorganic phosphate affects lung through altering protein translation, cell cycle, and angiogenesis in developing mice.Toxicol. Sci. Off. J. Soc. Toxicol.100,215-223(2007).

41. Xu, C. X. et al. High dietary inorganic phosphate enhances cap-dependent protein translation, cellcycle progression, and angiogenesis in the livers of young mice.Am. J. Physiol.-Gastrointest. Liver Physiol.295,G654-G663(2008). 
42. Bourgine, A. et al. Inorganic phosphate stimulates apoptosis in murine MO6-G3 odontoblast-like cells.Arch. Oral Biol.56,977-983(2011).

43. Lacerda-Abreu, M. A., Russo-Abrahão, T. \& Meyer-Fernandes, J. R. The Roles of Sodium-Independent Inorganic Phosphate Transporters in Inorganic Phosphate Homeostasis and in Cancer and Other Diseases.Int. J. Mol. Sci.21,9298(2020).

Figures 

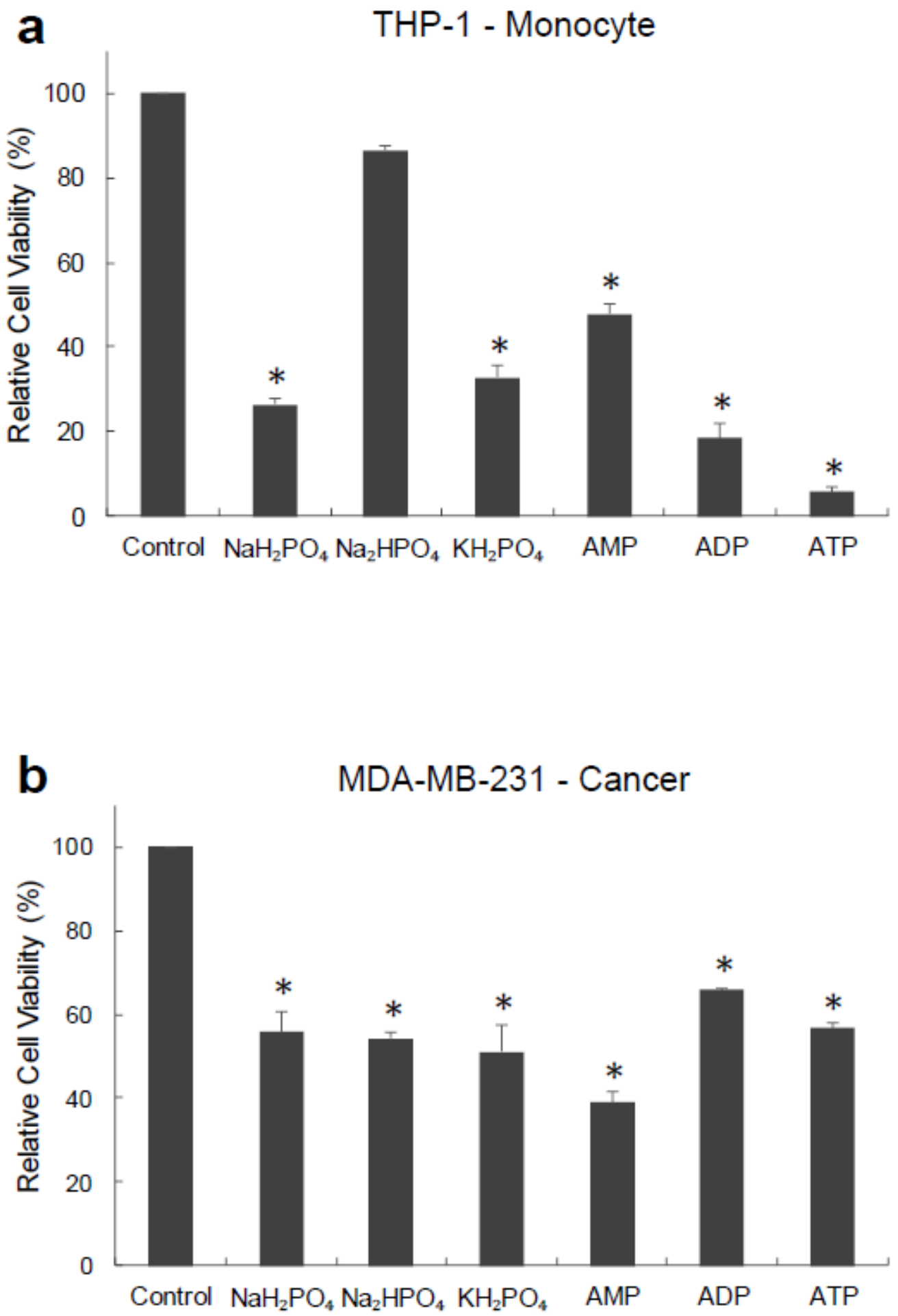

Figure 1

Toxicity of different phosphate compounds to (a) THP-1, human monocyte cell line, and (b) MDA-MB-231, human breast cancer cell line. All phosphate-containing compounds reduced viability of both cell types significantly $(p<0.05)$ except $\mathrm{Na} 2 \mathrm{HPO} 4$, which only reduced the viability of MDA-MB-231 cells but not that of THP-1 cells. 


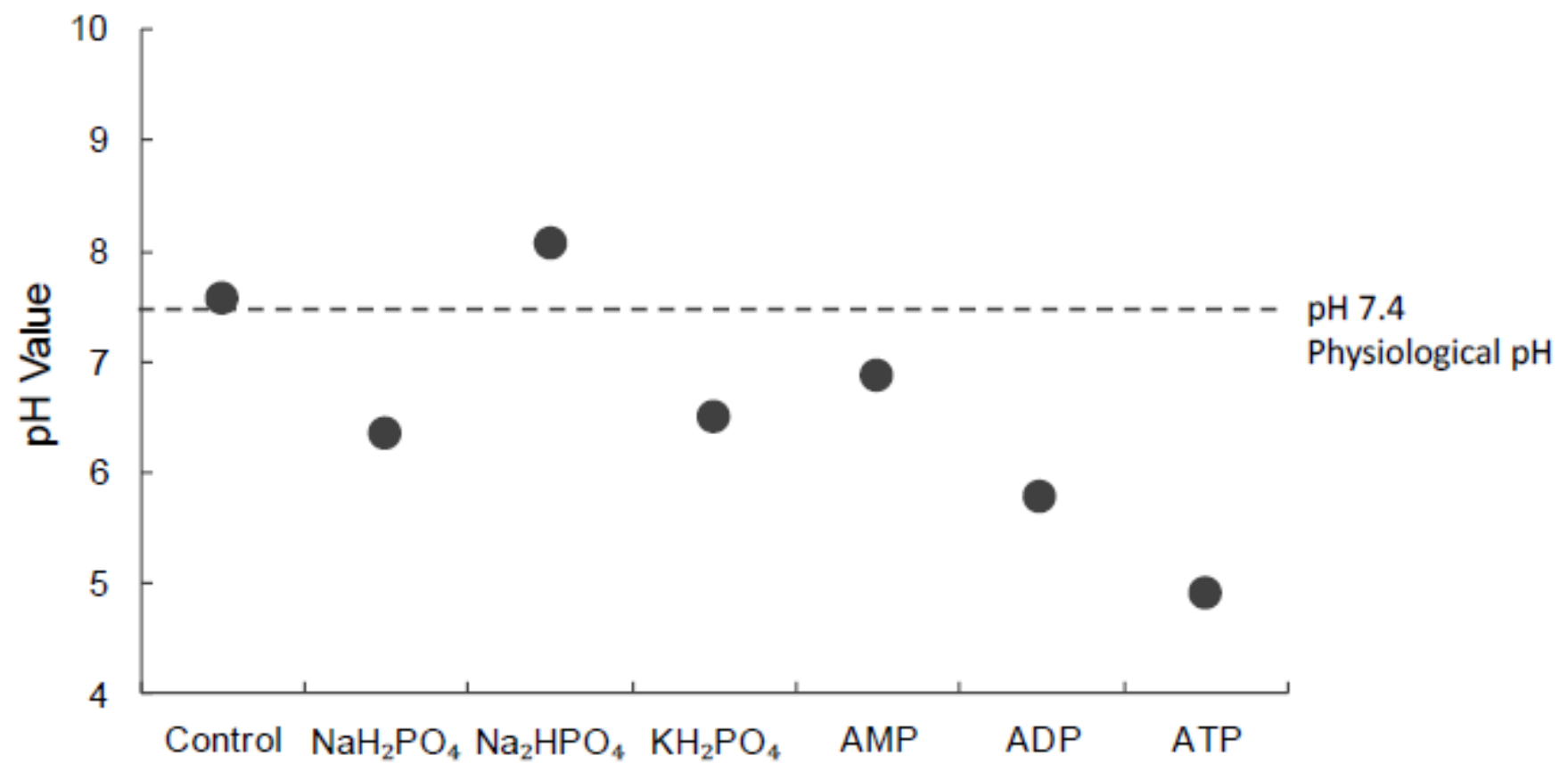

Figure 2

$\mathrm{pH}$ values for different phosphate compounds. All compounds produced acidic solutions except $\mathrm{Na} 2 \mathrm{HPO} 4$ which produced a basic solution. 
a

THP-1 - Monocyte
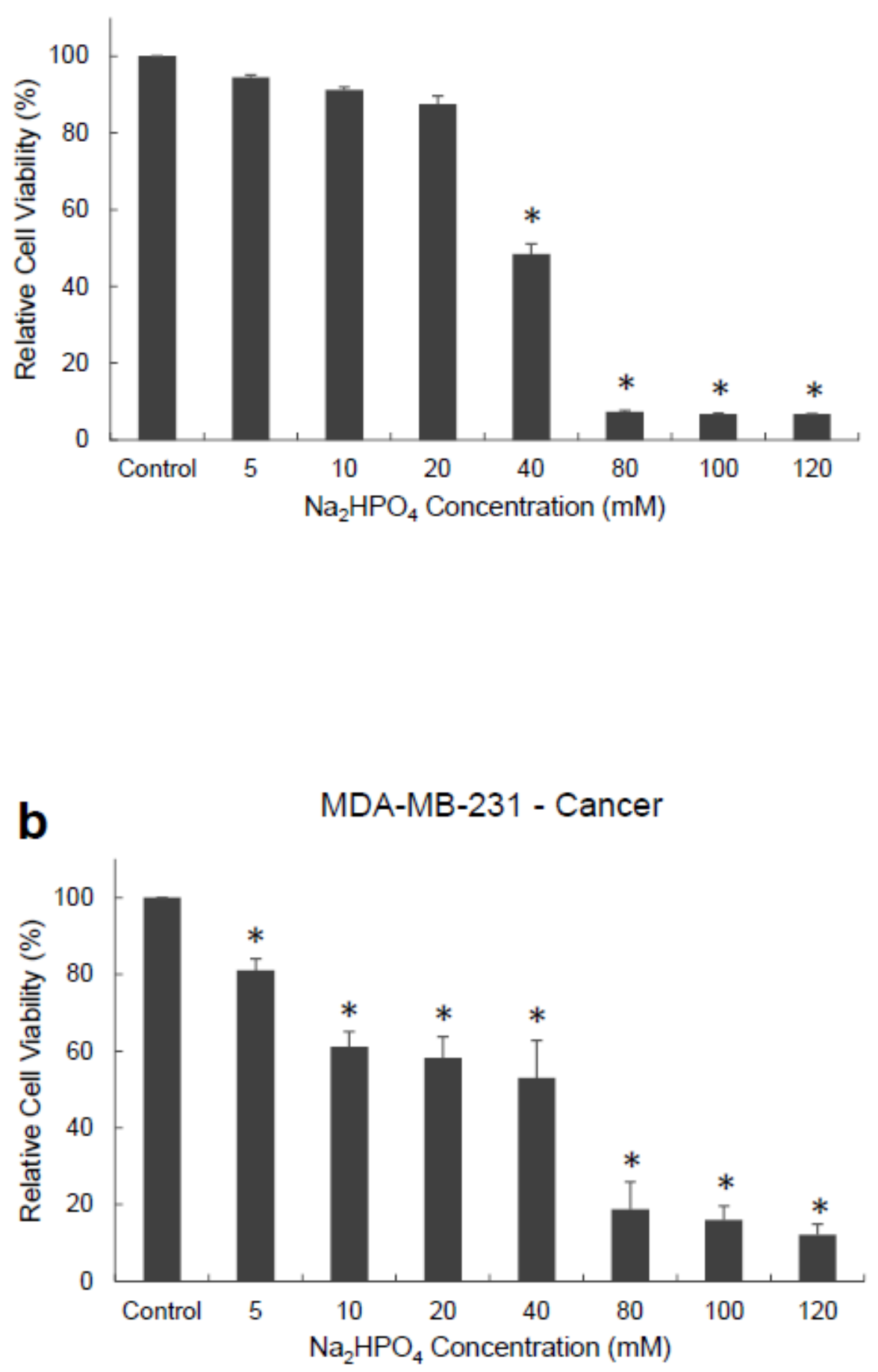

Figure 3

Toxicity of Sodium Phosphate Dibasic to (a) THP-1 and (b) MDA-MB-231 cells. At low concentrations (< or $=20 \mathrm{mM}$ ), Na2HPO4 is more toxic to MDA-MB-231 cells than it is to THP-1 cells. At high concentrations $(>20 \mathrm{mM}), \mathrm{Na} 2 \mathrm{HPO} 4$ is toxic to both cell types. 


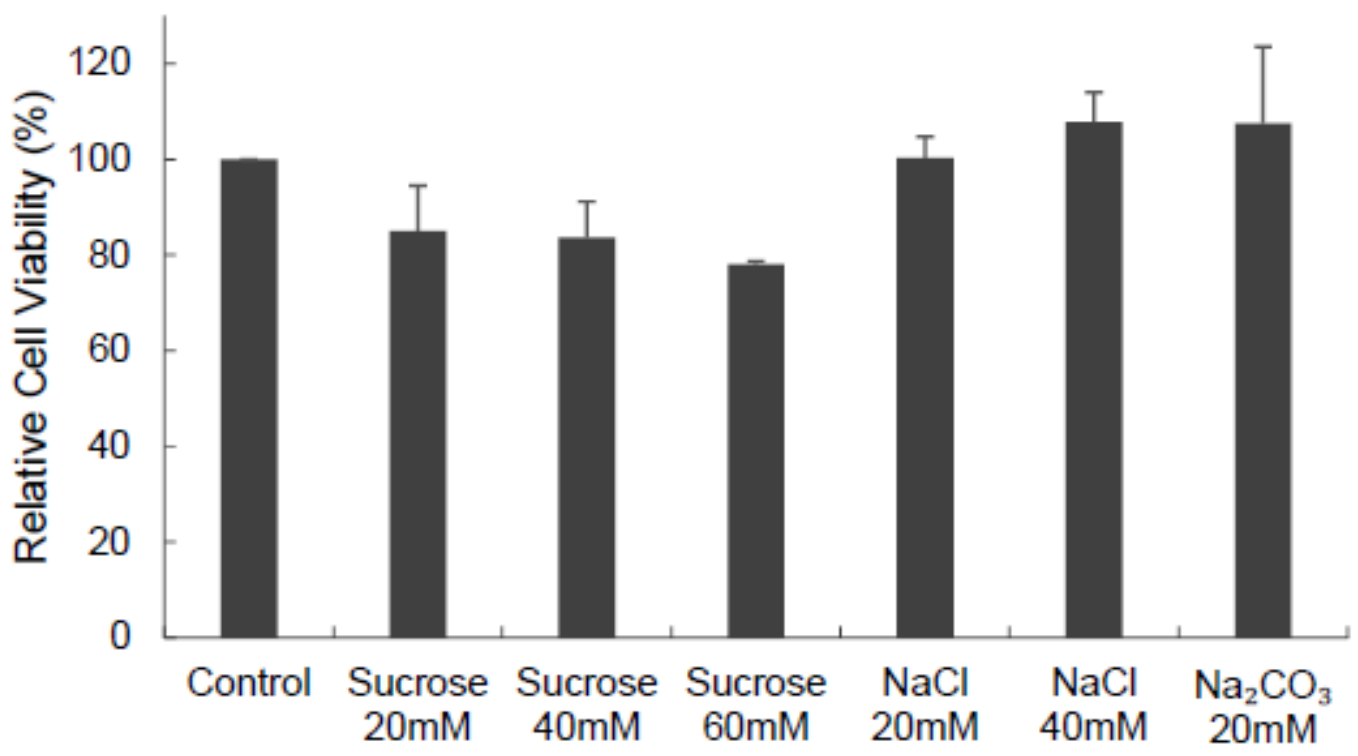

Figure 4

Effect of Sodium and osmotic pressure on MDA-MB-231 viability. None of the compounds caused a significant decrease in the viability of cells.

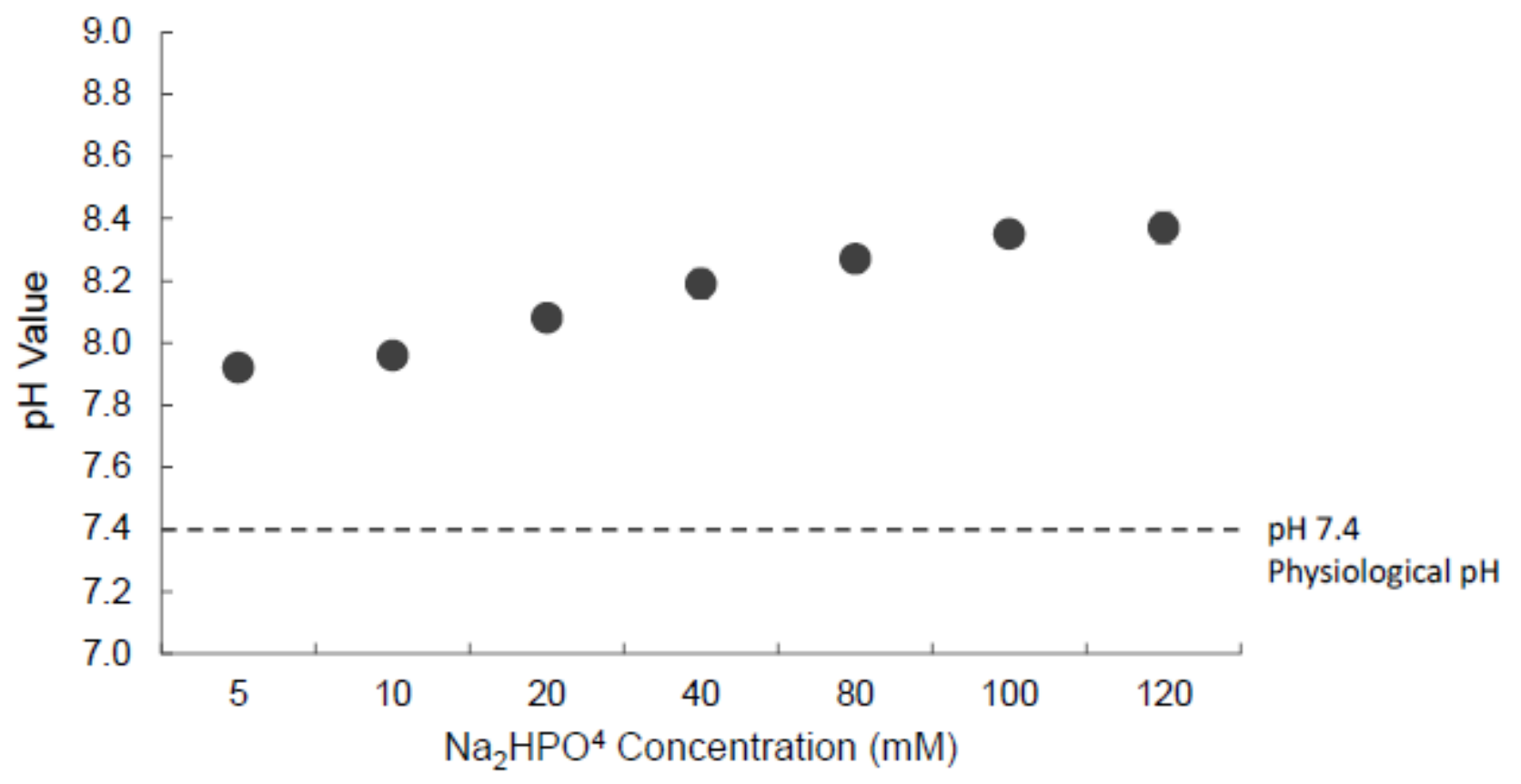

Figure 5

$\mathrm{pH}$ values for different concentrations of Sodium phosphate dibasic. As the concentration of HPO42increases, the $\mathrm{pH}$ of the solutions increases 

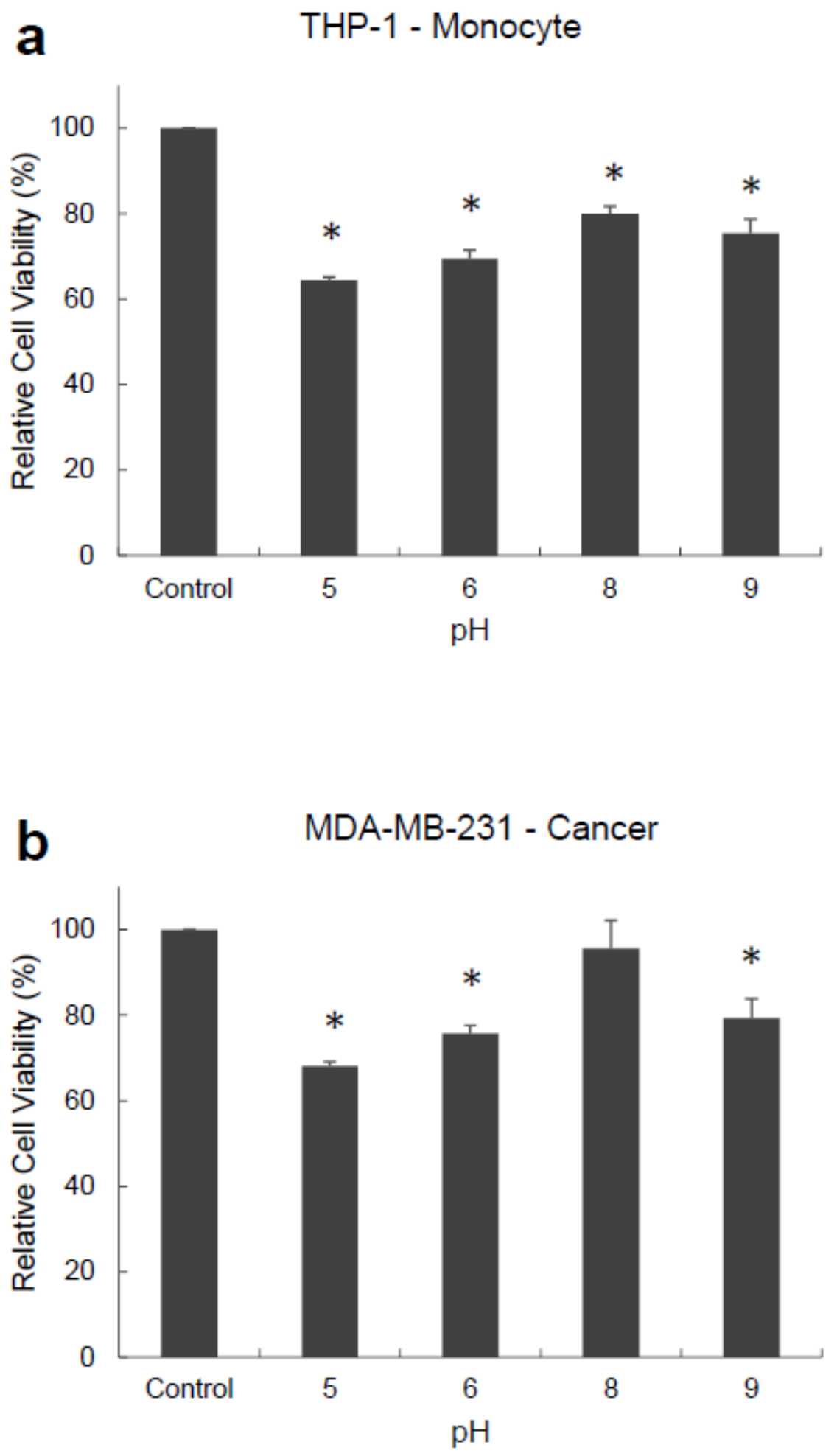

Figure 6

Viability of (a) THP-1 and (b) MDA-MB-231 cells at different pH levels. Acidic conditions caused a significant decrease in the viability of both cell types. For basic conditions, at $\mathrm{pH} 8$, the viability of THP-1 cells decreased significantly but that of MDA-MB-231 did not. At pH 9, viability of both cell types decreased significantly. 

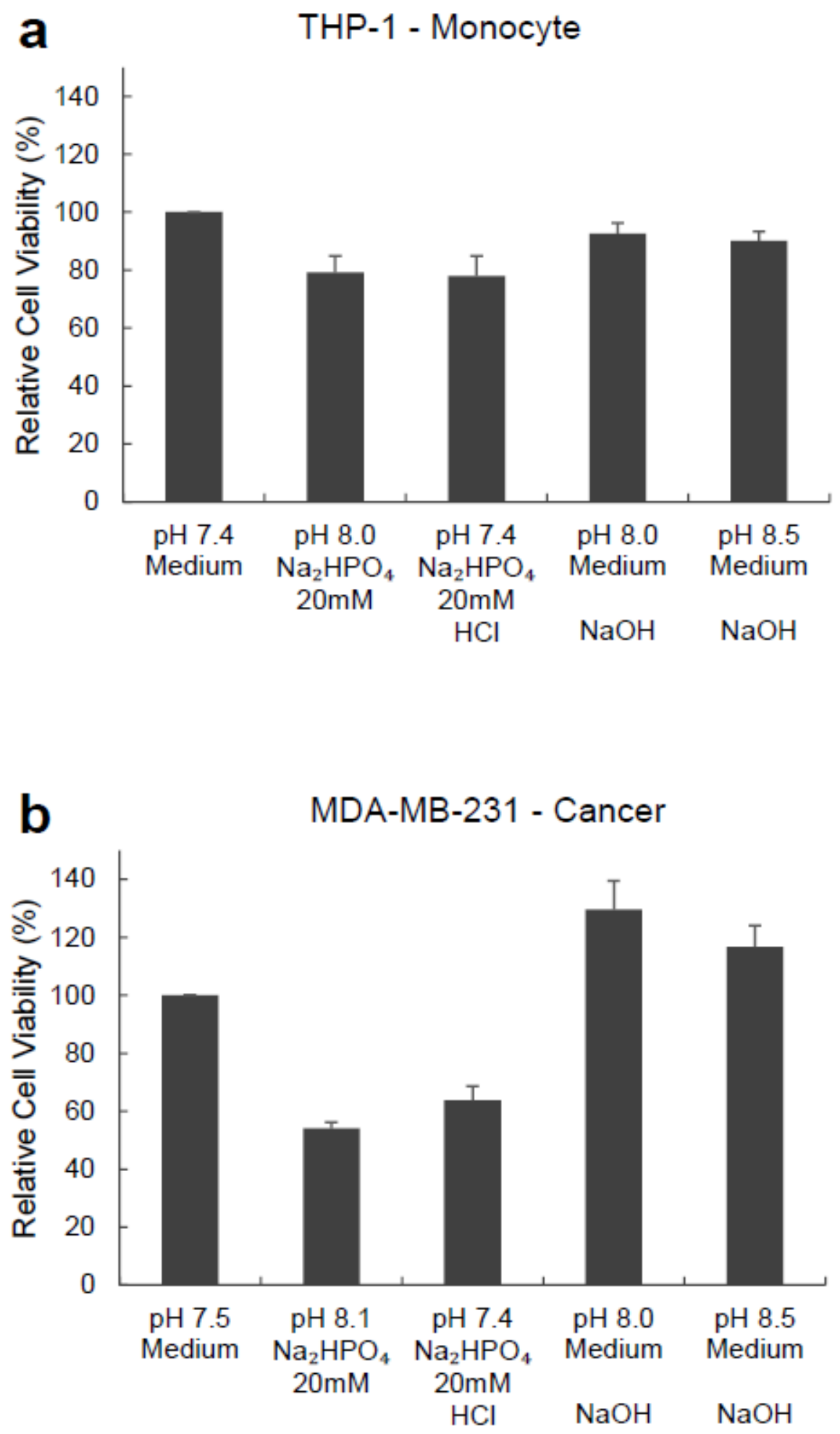

Figure 7

Viability of (a) THP-1 and (b) MDA-MB-231 cells after adding Sodium Phosphate Dibasic and adjusting $\mathrm{pH}$ to Physiological one. Adjusting the $\mathrm{pH}$ to physiological range (7.4-7.5) after adding Na2HPO4 increased the viability of cells by $18 \%$. Media only and media with $\mathrm{NaOH}$ are controls 


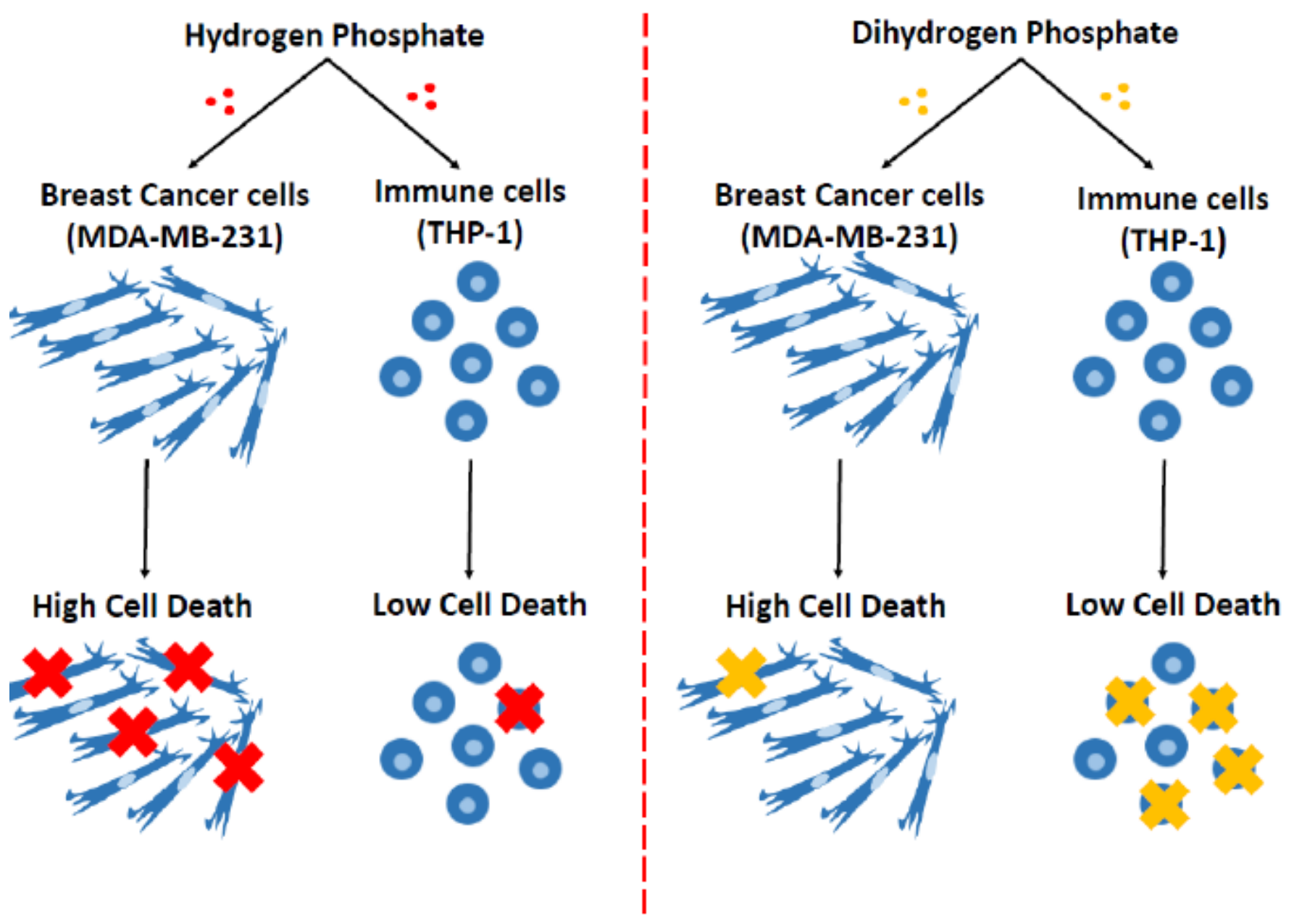

Figure 8

Schematic diagram - Effect of hydrogen phosphate on the cell viability of MDA-MB-231 and THP-1 cells

\section{Supplementary Files}

This is a list of supplementary files associated with this preprint. Click to download.

- 03SupportingInformationUpdated.pdf 